\title{
EFEKTIVITAS METODE LATIHAN AEROBIK DAN ANAEROBIK UNTUK MENURUNKAN TINGKAT OVERWEIGHT DAN OBESITAS
}

\author{
I Putu Agus Dharma Hita ${ }^{1}$ \\ ${ }^{1}$ Program Studi Ilmu Keolahragaan, Program Pascasarjana, \\ Universitas Negeri Yogyakarta, \\ Yogyakarta, Indonesia \\ e-mail: iputu.2019@student.uny.ac.id
}

\begin{abstract}
Abstrak
Overweight dan obesitas merupakan salah satu faktor resiko dari penyakit tidak menular yang bersifat kronis. Penyebab mendasar dari terjadinya overweight dan obesitas pada umumnya adalah ketidakseimbangan antara kalori yang dikonsumsi dan kalori yang dikeluarkan. Tujuan dari penelitian ini adalah untuk mengetahui perbedaan efektivitas antara metode latihan aerob dan metode latihan anaerob untuk menurunkan tingkat overweight dan obesitas. Metode yang digunakan dalam penelitian ini menggunakan metode studi literatur. Data dikumpulkan dengan metode studi pustaka, kemudian data yang diperoleh akan dikompulasi, dianalisis, dan disimpulkan sehingga mendapatkan sebuah kesimpulan. Setiap metode latihan yang akan diberikan kepada individu sebaiknya harus mempertimbangkan beberapa faktor, seperti kondisi individu itu sendiri dan tujuan dari metode latihan tersebut. Dalam suatu proses latihan harus mempertimbangkan kriteria FITT (frequency, intensity, time, type). Sumber energi utama yang digunakan oleh tubuh dalam melaksanakan aktivitas sangat tergantung dari intensitas dan durasi latihan yang dilakukan. Pada umumnya energi yang digunakan dalam latihan terdiri dari karbohidrat, lemak, dan phosphocreatine ( $\mathrm{PCr}$ ). $\mathrm{PCr}$ digunakan oleh tubuh saat melakukan durasi latihan yang relatif singkat, yaitu sekitar 110 detik. Sedangkan jika terjadi peningkatan pada durasi latihan, maka lemak didalam tubuh akan dijadikan sebagai sumber energi utama. Hal ini dapat terjadi dikarenakan adanya perubahan hormonal yang mengakibatkan perubahan penggunaan karbohidrat menjadi lemak yang digunakan sebagai sumber energi oleh tubuh selama proses latihan tersebut. Perubahan ini akan terjadi jika durasi latihan yang dilakukan berlangsung lebih dari 20 menit. Jadi, metode latihan aerobik lebih cocok diterapkan untuk individu yang ingin menurunkan berat badan, dikarenakan pelaksanaan dari metode latihan ini dilaksanakan dengan intensitas rendah namun durasi yang relatif lama. Sedangkan metode latihan anaerob lebih cocok diterapkan pada atlet atau individu yang ingin meningkatkan VO2max dikarenakan metode latihan ini dilaksanakan dengan intensitas tinggi namun durasi yang relatif lebih pendek.
\end{abstract}

Kata-kata kunci : overweight, obesitas, aerobik, anaerobik

\begin{abstract}
Overweight and obesity are risk factors for chronic non-communicable diseases. The fundamental cause of overweight and obesity in general is an imbalance between calories consumed and calories expended. The purpose of this study was to determine the difference in effectiveness between aerobic training methods and anaerobic training
\end{abstract}


methods to reduce overweight and obesity levels. The method used in this research is literature study method. The data were collected using the literature study method, then the data obtained would be compiled, analyzed, and concluded so as to get a conclusion. Each training method that will be given to individuals should consider several factors, such as the individual's own condition and the objectives of the training method. In a training process must consider the FITT criteria (frequency, intensity, time, type). The main source of energy used by the body in carrying out activities depends on the intensity and duration of the exercise carried out. In general, the energy used in exercise consists of carbohydrates, fats, and phosphocreatine (PCr). $\mathrm{PCr}$ is used by the body when doing a relatively short duration of exercise, which is about 1-10 seconds. Meanwhile, if there is an increase in exercise duration, the fat in the body will be used as the main energy source. This can occur due to hormonal changes that result in changes in the use of carbohydrates into fat which is used as an energy source by the body during the exercise process. This change will occur if the duration of the exercise lasts more than 20 minutes. So, the aerobic exercise method is more suitable for individuals who want to lose weight, because the implementation of this exercise method is carried out with low intensity but relatively long duration. Meanwhile, the anaerobic training method is more suitable for athletes or individuals who want to increase VO2max because this training method is carried out with high intensity but a relatively shorter duration.

Keywords : overweight, obesity, aerobics, anaerobic

\section{PENDAHULUAN}

Overweight atau kelebihan berat badan adalah suatu kondisi dimana individu memiliki $10-20 \%$ dari berat badan normal, sedangkan obesitas merupakan kondisi berat badan seseorang lebih dari $20 \%$ berat badan normal. Pada umunya kondisi overweight dan obesitas merupakan kondisi dimana terdapat lemak yang berlebih di dalam tubuh, sehingga dapat menimbulkan resiko terhadap tingkat kesehatan individu dan merupakan faktor penyebab dari munculnya penyakit - penyakit degeneratif.
Kondisi ini dapat di alami oleh setiap golongan umur, baik yang berjenis kelamin laki - laki maupun perempuan.

Yang dapat membedakan antara kondisi overweight atau obesitas pada individu yaitu dengan cara melakukan perhitungan Indeks Massa Tubuh (IMT). Menurut WHO tahun 2000 (P2PTM 2018) cara menghitung IMT dengan menggunakan berat badan dalam satuan kilogram dibagi kuadrat tinggi badan dalam satuan meter, berikut klasifikasi berat badan berdasarkan IMT

Tabel 1. Klasifikasi Berat Badan Berdasarkan IMT Menurut Kriteria Asia Pasifik WHO Tahun 2000 (P2PTM 2018)

\begin{tabular}{cc}
\hline Kategori & IMT \\
\hline Berat Badan kurang & $<18,5 \mathrm{~kg} / \mathrm{m}^{2}$ \\
\hline Normal & $18,5-22,9 \mathrm{~kg} / \mathrm{m}^{2}$ \\
\hline Berat badan lebih $($ Overweight $)$ & $23-24,9 \mathrm{~kg} / \mathrm{m}^{2}$ \\
\hline Obesitas I & $25-29,9 \mathrm{~kg} / \mathrm{m}^{2}$ \\
\hline Obesitas II & $>30 \mathrm{~kg} / \mathrm{m}^{2}$ \\
\hline
\end{tabular}


Menurut (Nurhayati et al. 2018) obesitas merupakan salah satu faktor resiko penyakit tidak menular yang bersifat kronis seperti hipertensi dan diabetes. Tetapi obesitas merupakan salah satu faktor resiko yang dapat dimodifikasi. Maka dari itu, obesitas menjadi salah satu fokus utama dari WHO dalam mengurangi angka penyakit tidak menular. Kegemukan merupakan salah satu faktor resiko penting dari berbagai penyakit dan dapat mengurangi keindahan bentuk tubuh (Sugiarti and Noor 2008). Penyebab mendasar dari terjadinya overweight dan obesitas pada umumnya adalah ketidakseimbangan energi antara kalori yang dikonsumsi dan kalori yang dikeluarkan. Perubahan pola makan yang meningkat dan aktivitas fisik yang menurun adalah faktor paling utama penyebab terjadinya overweight dan obesitas. Obesitas adalah salah satu faktor risiko dengan dampak terbesar pada pengembangan DM dan resistensi insulin (Rodríguez-gutiérrez et al. 2012). Obesitas merupakan penyakit multifaktorial yang diduga bahwa sebagian besar obesitas disebabkan karena interaksi antara faktor genetik dan faktor lingkungan, antara lain adalah aktivitas fisik, gaya hidup, sosial ekonomi, dan nutrisional yaitu perilaku makan dan pemberian makanan padat terlalu dini pada bayi (Pratiwi, Masriadi, and Basri 2018).

Menurut penelitian yang dilakukan oleh (Hamalding, Risna, and Susanti 2019) yaitu bahwa faktor penyebab obesitas adalah aktivitas fisik, konsumsi fastfood, menonton TV, dan penggunaan gadget. Pernyataan ini juga diperkuat oleh penelitian yang dilakukan oleh (Septiani and Raharjo 2017) yang menyatakan bahwa pola konsumsi fast food, aktivitas fisik, dan juga keturunan memiliki pengaruh terhadap kejadian obesitas. Rendahnya tingkat aktivitas fisik yang dilakukan sangat berpengaruh terhadap terjadinya obesitas, banyak anak - anak remaja lebih banyak menghabiskan waktu hanya untuk bermain gadget dan menonton TV. Selain itu, faktor dari ternyadinya obesitas antara lain yaitu asupan energi, dimana asupan energi yang tinggi 7 kali lipat lebih berisiko obesitas dibandingkan dengan asupan energi yang rendah, selain itu asupan protein juga merupakan faktor risiko terjadinya obesitas dimana asupan protein yang tinggi 8 kali lipat berisiko dibandingkan dengan asupan protein yang rendah, dan aktivitas fisik rendah juga merupakan faktor risiko terjadinya obesitas dimana aktivitas fisik yang rendah 7 kali lipat berisiko obesitas dibandingkan dengan aktivits fisik yang cukup (Kosnayani and Aisyah 2016).

Pravalensi obesitas diseluruh dunia terus mengalami peningkatan yaitu hampir tiga kali lipat sejak tahun 1975. Pada 2016, lebih dari 1,9 miliar orang dewasa umur 18 tahun ke atas mengalami overweight dan dari jumlah tersebut terdapat lebih dari 650 juta orang mengalami obesitas. Selain itu, pada tahun 2019 terdapat 38 juta anak di bawah usia 5 tahun mengalami overweight dan obesitas (World Health Organization 2020). Untuk di Indonesia sendiri, menurut data dari Riskesdas 2018 (Kemenkes 2019) untuk anak umur 5-12 tahun terdapat $10,8 \%$ untuk overweight dan 9,2\% untuk obesitas, pada remaja umur 13-15 tahun terdapat $11,2 \%$ untuk overweight dan $4,8 \%$ untuk obesitas $4,8 \%$, sedangkan pada remaja umur 16-18 tahun terdapat 9,5\% untuk overweight dan $4,0 \%$ untuk obesitas $4,0 \%$. Besarnya pravalensi kejadian overweight dan obesitas di Indonesia ini sangat memberikan efek besar terhadap tingkat kesehatan seseorang. Prevalensi kelebihan berat badan dan obesitas terus meningkat dan mencapai proporsi epidemi di negara - negara maju dan 
negara berkembang. Karena hubungannya yang kuat antara obesitas dan penyakit kardiovaskular, diabetes tipe 2 dan penyakit kronis lainnya (Wilborn et al. 2005). Peningkatan overweight dan obesitas ini merupakan faktor utama dari terjadinya penyakit penyakit degeneratif seperti penyakit kardiovaskular (seperti penyakit jantung dan stroke), diabetes, penyakit degeneratif sendi, serta beberapa kanker (seperti endometrium, payudara, ovarium, prostat, hati, kandung empedu, ginjal, dan usus besar). Selain itu, risiko penyakit akibat obesitas antara lain yaitu tekanan darah tinggi, kadar gula darah tinggu (diabetes), kadar kolestrol tinggi, lemak darah tinggi (trigliserida), dan beberapa penyakit lainnya.

Obesitas sering menjadi masalah seumur hidup. Ketika terjadi peningkatan berat badan berlebih, tidak akan mudah untuk menurunkannya. Harus banyak proses metode - metode yang dilakukan, dan jika sudah turun maka harus bekerja keras menjaga berat badan agar tidak mengalami kelebihan berat badan kembali. Cara mencegah terjadinya overweight dan obesitas yang paling banyak dilakukan adalah dengan melakukan aktivitas olahraga atau latihan - latihan tertentu agar kalori yang terkumpul didalam tubuh akibat mengkonsumsi makanan yang berlebih dapat dikeluarkan. Selain untuk mencegah terjadinya overweight dan obesitas, aktivitas olahraga juga bertujuan untuk menjaga kesehatan tubuh secara menyeluruh. Latihan yang banyak dilakukan adalah metode latihan aerob dan metode latihan anaerob.

Latihan aerob pada dasarnya merupakan latihan yang sumber energinya berasal dari oksigen dan latihannya dilaksanakan secara terus menerus dan melibatkan otot - otot besar. Latihan ini dilakukan dengan intensitas sedang yaitu $60-80 \%$ dari
Maximal Heart Rate (MHR) dan 50 $85 \%$ dari penggunaan maksimal oksigen dan memerlukan durasi yang relatif lama yaitu sekitar $20-50$ menit dengan frekuensi 3 kali seminggu. Manfaat dari latihan aerob adalah untuk menjaga kesehatan paru - paru, jantung, sistem peredaran darah, mengendalikan berat badan, dan sebagainya. Contoh dari latihan aerob adalah berjalan, bersepeda, jogging, senam, dan lain - lain.

Sedangkan latihan anaerob merupakan metode latihan yang sumber energinya tidak memerlukan oksigen. Energi didapatkan dari pembentukan ATP melalui sumber energi yang berasal dari kreatin fosfat dan glikogen. Latihan anaerob dilakukan dengan intensitas yang tinggi namun dengan durasi yang singkat. Latihan anaerob merupakan latihan yang dilakukan dengan intensif dan berat, serta sangat menguras stamina. Manfaat utama dari latihan anaerob adalah dapat membangun kekuatan otot menjadi lebih kuat. Dengan latihan tersebut maka akan berpengaruh langsung terhadap pembakaran lemak yang terkumpul didalam tubuh kita. Contoh latihan anaerob adalah sprint, push-up, sit-up, pull-up, dan lain - lain.

\section{METODE}

Metode yang digunakan dalam penelitian ini menggunakan metode studi literatur. Data dikumpulkan dengan metode studi pustaka, kemudian data yang diperoleh akan dikompulasi, dianalisis, dan disimpulkan sehingga mendapatkan sebuah kesimpulan.

\section{HASIL DAN PEMBAHASAN}

Setiap metode latihan yang akan diberikan kepada individu harus mempertimbangkan beberapa faktor, seperti kondisi individu itu sendiri dan tujuan dilakukan metode latihan tersebut, 
sehingga tujuan yang dicapai akan berhasil. Keberhasilan suatu tujuan sangat berpengaruh dari seorang pelatih. Dalam proses latihan harus mempertimbangkan kriteria FITT (frequency, intensity, time, type). Frekuensi adalah seberapa sering aktivitas tersebut dilakukan, berapa hari dalam satu minggu, biasanya frekuensi latihan dalam seminggu itu kisaran 3-5 kali dan tergantung dengan kondisi tubuh individu. Intensitas adalah seberapa keras suatu aktivitas dilakukan. Biasanya diklasifikasikan menjadi intensitas rendah, sedang, dan tinggi. Pada tahap awal sebaiknya dilakukan dengan intensitas sedang $(64-76 \%$ dari Maximal Heart Rate) dan terus ditingkatkan seirining berjalannya waktu. Waktu mengacu pada durasi, seberapa lama suatu aktivitas dilakukan dalam satu pertemuan. Biasanya intensitas sedang dilaksanakan selama 30 - 60 menit setiap latihan. Dan jenis aktivitas adalah jenis - jenis aktivitas fisik yang dilakukan, biasanya seperti jalan, jogging, bersepeda, berenang, dan sebagainya.

Metode latihan aerob sangat banyak dijadikan salah satu pilihan untuk mengontrol berat badan yang berlebih. Metode ini dilakukan dengan intensitas rendah namun durasi yang cukup lama. Energi yang digunakan dalam latihan ini bersumber dari oksigen. Menurut (Palar, Wongkar, and Ticoalu 2015) metode latihan aerobik merupakan metode dengan aktivitas olahraga yang dilaksanakan secara sistematis dengan peningkatan beban secara bertahap dan menggunakan energi yang berasal dari pembakaran dengan menggunakan oksigen dan membutuhkan oksigen tanpa menimbulkan kelelahan. Metode latihan aerobik ini berguna untuk mempercepat proses metabolisme tubuh dan memungkinkan untuk dapat menyerap dan memanfaatkan nutrisi yang lebih besar dari makanan yang kita konsumsi (Mubarak, Kinanti, and Raharjo 2019). Salah satu jenis latihan yang banyak digunakan adalah aktivitas senam aerobik. Senam aerobik ini banyak dilakukan karena pada umumnya senam ini dilakukan dengan intensitas yang rendah tetapi durasi yang lama yaitu sekitar 30 - 60 menit. Manfaat seseorang melakukan senam aerobik adalah salah satu cara yang baik untuk membakar kalori dan lemak yang ada ditubuh kita, dikarenakan kelompok otot - otot besar bergerak secara dinamis dari bagian atas dan bagian bawah tubuh.

Banyak penelitian - penelitian yang sudah dilakukan yang bertujuan untuk membuktikan pengaruh dari metode latihan aerobik. Salah satunya penelitian yang dilakukan oleh (Sitepu, Tangkudung, and Puspitorini 2020) yaitu terdapat pengaruh yang signifikan dari latihan senam aerobik terhadap penurunan persentase lemak tubuh. Selain itu penelitian yang dilakukan oleh (Utomo, Junaidi, and Rahayu 2012) menunjukkan bahwa latihan senam aerobik terbukti menurunkan berat badan sebesar $66,78 \%$, lemak tubuh sebesar $86,42 \%$, dan kadar kolesterol sebesar $27,67 \%$. Simpulan dari penelitian ini ada pengaruh yang signifikan dari latihan senam aerobik low impact terhadap penurunan berat badan, persen lemak tubuh dan kadar kolesterol pada penderita obesitas. Penelitian yang dilakukan oleh (Pratiwi et al. 2018) juga menunjukan bahwa terdapat pengaruh penurunan berat badan pada kelompok yang diberikan senam aerobik.

Selain metode aerob, metode yang banyak digunakan adalah metode anaerob. Metode ini merupakan metode yang bisa dianggap sebagai metode kebalikan dari metode aerob. Metode anaerob adalah metode yang dilakukan dengan intensitas yang tinggi namun 
durasi yang relatif pendek. Latihan ini dilakukan dengan sangat intensif. Menurut (Vidiari et al. 2017) salah satu bentuk metode latihan yang dapat meningkatkan ambang anaerobik adalah HIIT yaitu metode latihan yang di setiap sesinya merupakan metode latihan dengan intensitas yang tinggi dan dengan kecepatan atau beban latihan di atas ambang anaerobik dengan waktu yang singkat.

Dengan intensitas yang tinggi ini, seorang pelatih harus mengetahui bagaimana kondisi individu yang dilatihnya. Penelitian yang dilakukan oleh (Emerson et al. 2016) mengatakan bahwa latihan yang dilakukan terlalu lama melebihi 90 menit terkadang sulit dilakukan oleh individu yang mengalami overweight dan obesitas. Metode latihan fisik anaerobik pada kecepatan $6 \mathrm{kph}$ sudah mencapai kadar ambang asam laktat yaitu $5.07 \mathrm{Mmol} / 1$ menggunakan treadmill, selain itu waktu latihan fisik anaerobik pada 1 menit sudah mencapai kadar ambang batas asam laktat (Rohaya 2014). Selain itu, menurut penelitian yang dilakukan oleh (Putra, Fitria, and Putri 2018) menyatakan bahwa HIIT memberikan dampak yang signifikan terhadap penurunan persentase lemak wanita menopause penderita obesitas. Maka dengan memberikan perlakuan HIIT persentase lemak dalam tubuh menurun lebih banyak jika dibandingkan dengan kelompok kontrol yang hanya diberikan perlakuan berupa kardio biasa. Hal ini dikarenakan HIIT, memberikan intensitas latihan yang lebih tinggi meskipun dengan rentangan waktu yang lebih singkat. Sehingga pembakaran lemak lebih efektif jika dibandingkan dengan kardio biasa. HIIT dapat dilaksanakan di rumah ataupun di taman disekitar rumah. Oleh karena itu HIIT sangat sesuai untuk negara - negara maju dan negara - negara berkembang yang sangat menghargai waktu. eimbangan, dan aktifitas. Jika dibandingkan dengan latihan kardio standar pada umunya, HIIT lebih efektif membakar lemak tubuh. Sedangkan latihan kardio bertujuan untuk melatih gerakan jantung, sehingga tidak signifikan dalam menurunkan kadar lemak dalam tubuh. Berbeda dengan HIIT yang dapat menurunkan kadar lemak dalam tubuh dan melatih gerakan jantung.

Banyak penelitian yang dilakukan terhadap metode ini. Salah satunya yaitu penelitian yang dilakukan oleh (Komala, Riyadi, and Setiawan 2016) menunjukan bahwa moderate intensity training (MIT), and high intensity interval training (HIIT) sama - sama efektif dalam menurunkan IMT dan PLT remaja obesitas. Latihan dengan intensitas sedang dan berat sebanyak tiga kali per minggu dapat dijadikan salah satu cara untuk menurunkan berat badan sehingga mencegah peningkatan obesitas. HIIT lebih baik diterapkan pada atlet atau seseorang yang ingin meningkatkan kebugaran aerobik (VO2max). MIT lebih disarankan untuk seseorang yang ingin menurunkan berat badan dan persen lemak tubuh. Latihan dengan intensitas rendah sampai sedang memiliki kecenderungan dalam memperbaiki status gizi dan persen lemak tubu (Komala et al. 2016).

\section{SIMPULAN DAN SARAN}

Kesimpulan pada penelitian ini yaitu tentang perbedaan efektivitas antara metode latihan aerob dan metode latihan anaerob terhadap penurunan tingkat overweight dan obesitas. Sumber energi utama yang digunakan oleh tubuh dalam melaksanakan aktivitas sangat tergantung dari intensitas dan durasi latihan yang dilakukan. Pada umumnya energi yang digunakan dalam latihan terdiri dari karbohidrat, lemak, dan phosphocreatine (PCr). $\mathrm{PCr}$ digunakan oleh tubuh saat melakukan durasi latihan 
yang relatif singkat, yaitu sekitar 1-10 detik. Sedangkan jika terjadi peningkatan pada durasi latihan, maka lemak didalam tubuh akan dijadikan sebagai sumber energi utama. Hal ini dapat terjadi dikarenakan adanya perubahan hormonal yang mengakibatkan perubahan penggunaan karbohidrat menjadi lemak yang digunakan sebagai sumber energi oleh tubuh selama proses latihan tersebut. Perubahan ini akan terjadi jika durasi latihan yang dilakukan berlangsung lebih dari 20 menit. Jadi, metode latihan aerobik lebih cocok diterapkan untuk individu yang ingin menurunkan berat badan, dikarenakan pelaksanaan dari metode latihan ini dilaksanakan dengan intensitas rendah namun durasi yang relatif lama. Sedangkan metode latihan anaerob lebih cocok diterapkan pada atlet atau individu yang ingin meningkatkan VO2max dikarenakan metode latihan ini dilaksanakan dengan intensitas tinggi namun durasi yang relatif lebih pendek.

Saran untuk penelitian berikutnya sebaiknya menambahkan variabel untuk diteliti sehingga pembahasan akan lebih luas dan hasil dari sebuah penelitian akan menjadi lebih baik.

\section{DAFTAR PUSTAKA}

Emerson, Sam R., Stephanie P. Kurti, Brian S. Snyder, Karthikeyan Sitaraman, Mark D. Haub, and Sara K. Rosenkranz. 2016. "Effects Of Thirty And Sixty Minutes Of Moderate-Intensity Aerobic Exercise On Postprandial Lipemia And Inflammation In Overweight Men: A Randomized Cross-Over Study." Journal of the International Society of Sports Nutrition 1-12.

Hamalding, Hermawati, Risna, and Rahma Sri Susanti. 2019. "Hubungan Gaya Hidup Terhadap
Overweight Dan Obesitas Pada Remaja Putri Di Sma Negeri 11 Makassar." Jurnal Komunitas Kesehatan Masyarakat 1(11):1-6.

Kemenkes. 2019. "Laporan Nasional Riskesdas 2018."

Komala, Ramadhana, Hadi Riyadi, and Budi Setiawan. 2016. "Latihan Intensitas Sedang Dan Berat Memperbaiki Vo2Max, Indeks Massa Tubuh, Dan Persen Lemak Tubuh Remaja Obes." 11(November):211-18.

Kosnayani, Ai Sri, and Iseu Siti Aisyah. 2016. "Faktor Risiko Yang Berhubungan Dengan Obesitas Remaja." Jurnal Siliwangi 2(2):2014-17.

Mubarak, Syahrul, Rias Gesang Kinanti, and Slamet Raharjo. 2019. "Pengaruh Senam Aerobik Intensitas Ringan Dan Sedang Terhadap Kadar Kolesterol Total Pada Perempuan Obes Di Kota Batu." Jurnal Sport Science.

Nurhayati, Titing, Putri Halleyana, Astrid Feinisa, Rahma Kharunnisa, M. Afif Aulia, M. Hasan Bashari, Dimas Erlangga L, Hermin Aminah U, Rani Septrina, Deshita Rimadania, Diki Ginanjar N, Pipih Pitriani, Aldy Riofany, Dede Rina A, Grace D'Olivia, M. Rizki Wibawa, and Putri Sekar U. 2018. "Aktivitas Fisik Yang Tinggi Dapat Mengatasi Obesitas Sentral." Jurnal Pendidikan Jasmani Dan Olahraga 3(2):14852.

P2PTM. 2018. "Klasifikasi Obesitas Setelah Pengukuran IMT." P2PTM Kemenkes RI 1-2.

Palar, Chrisly M., Djon Wongkar, and Shane H. R. Ticoalu. 2015. "Manfaat Latihan Olahraga Aerobik Terhadap Kebugaran Fisik Manusia." Jurnal EBiomedik (EBm) 3(April). 
Pratiwi, Indriani, Masriadi, and Muh Basri. 2018. "Pengaruh Senam Aerobik Terhadap Penurunan Berat Badan Remaja Obesitas Di SMP Katolik Rajawali Makassar Tahun 2017." 1(2):76-82.

Putra, Muarif Arhas, Rahmi Fitria, and Rahmah Evita Putri. 2018. "Pengaruh High Intensity Interval Training (Hiit) Terhadap Persentase Lemak Tubuh Wanita Menopause Penderita Obesitas." 2:158-66.

Rodríguez-gutiérrez, René, Fernando J. Lavalle-gonzález, Laura E. Martínez-garza, Erick Landerosolvera, Juan C. López-alvarenga, Maria R. Torres-sepúlveda, Jose G. González-gonzález, Leonardo G. Mancillas-adame, Bertha Salazar-gonzalez, and Jesus Z. Villarreal-pérez. 2012. "Impact of an Exercise Program on Acylcarnitines in Obesity: A Prospective Controlled Study." Journal of the International Society of Sports Nutrition 1-8.

Rohaya. 2014. "Pengaruh Latihan Fisik Anaerobik Terhadap Kadar Ambang Batas Asam Laktat Pada Orang Yang Terlatih." Jurnal Kesehatan Poltekkes Palembang 1.

Septiani, Riswanti, and Bambang Budi Raharjo. 2017. "Pola Konsumsi Fast Food, Aktivitas Fisik Dan Faktor Keturunan Terhadap Kejadian Obesitas (Studi Kasus Pada Siswa SD Negeri 01 Tonjong Kecamatan Tonjong Kebupaten Brebes)." 2(3):262-69.

Sitepu, M. Syukur Zulbandi, James Tangkudung, and Wahyuningtyas Puspitorini. 2020. "Pengaruh Latihan Senam Aerobik Dan Motivasi Berolahraga Terhadap Penurunan Persentase Lemak Tubuh." Jurnal Penjaskesrek 7(1):15-27.
Sugiarti, Nanik, and Zulkhah Noor. 2008. "Pengaruh Program Olahraga Umum (Senam Aerobik) Dan Khusus (Body Language Dan Senam Aerobik) Terhadap Penurunan Berat Badan." Jurnal Mutiara Medika 8(1):1-8.

Utomo, Galih Tri, Said Junaidi, and Setya Rahayu. 2012. "Latihan Senam Aerobik Untuk Menurunkan Berat Badan, Lemak, Dan Kolesterol." 1(1).

Vidiari, Indira, Putu Gede Adiatmika, Luh Made Indah S. H. Adiputra, Tirtayasa, Made Muliarta, Adiartha Griadhi, and 1. 2017. "High Intensity Interval Training (HIIT) Lebih Meningkatkan Ambang Anaerobik Daripada Steady State Training Pada Siswa Anggota Kelompok Ekstrakurikuler Atletik Lari Jarak Pendek." 5(3):62-70.

Wilborn, Colin, Jacqueline Beckham, Bill Campbell, Travis Harvey, Melyn Galbreath, Paul La Bounty, Erika Nassar, Jennifer Wismann, and Richard Kreider. 2005. "Obesity: Prevalence, Theories, Medical Consequences, Management, and Research Directions." Journal of the International Society of Sports Nutrition 2(2):4-31.

World Health Organization. 2020. "Obesity and Overweight." (April):1-6. 